\title{
ANALISIS KINERJA PENDAPATAN ASLI DAERAH KABUPATEN
} BATANGHARI 2012-2016

\author{
${ }^{1}$ Jasasila \\ ${ }^{1}$ Sekolah Tinggi Ilmu Ekonomi Muara Bulian \\ jasasila@yahoo.co.id
}

\begin{abstract}
This Penetilian formulate the problem how the Performance of Kabupaten Batanghari Original Income for the period 2012-2016 with the scope of the discussion, PAD Development, PAD Effectiveness and Financial Independence Kabupaten Batanghari during 2012-2016, while the purpose of this study to determine the performance of the original income of Batanghari seen from the development of PAD, PAD Effectiveness and Regional Financial Independence. The type of data used in this study is a collection of information or facts recorded through direct observation while the data used sourced from relevant agencies related to research topics to get the performance of the original income of Kabupaten Batanghari 2012-2016 the authors do the analysis by using analysis of the development of PAD, Analysis of effectiveness and independence analysis. From the results of the analysis obtained the result that the development of PAD Kabupate Batanghari from 2012 to 2016 is fluctuating, where the largest increase occurred in 2014 that amounted to $39.87 \%$, but in 2015 there was a decrease in realization of $P A D$ by $2.65 \%$, this decrease one of which is caused by the realization of Pajak Bumi Bangunan (PBB) revenues of rural and urban sector in Kabupaten Batanghari 2015 decreased as the impact of falling prices of oil palm and rubber. This Pajak Bumi Bangunan (PBB) compulsory reduction is based on Pajak Bumi Bangunan realized revenue per kecamatan from January to September 2015. For the effectiveness of PAD Kabupaten Batanghari shows that in 2012, 2015 and 2016 are categorized quite effectively with the calculation of $84 \%, 85 \%$ and $82 \%$, respectively in 2013 and 2014 respectively $110 \%$ and $103 \%$ are categorized as very effective, from the calculation result according to the interval scale, financial independence of Kabupaten Batanghari is below 10\%, it means that financial independence of Kabupaten Batanghari is very less.
\end{abstract}

Keywords: Performance, PAD, Development, Effectiveness, Independence

\section{PENDAHULUAN}

Pembangunan merupakan suatu proses kegiatan yang dilakukan dalam rangka pengembangan atau mengadakan perubahan-perubahan kearah keadaan yang lebih baik, dengan menciptakan keselarasan dan keseimbangan seluruh kegiatan pembangunan dengan cara pemerataan pembangunan dan hasil-hasilnya bagi seluruh rakyat indonesia. Untuk menjalankan pembangunan tersebut dibutuhkan dana yang tidak sedikit. Hal ini juga sebagai penentu berhasil tidaknya suatu pembangunan secara maksimal. Disinilah peranan pajak cukup besar, karena pajak merupakan salah satu unsur terbesar dalam menghasilkan pendapatan daerah dimana dari pajak inilah akan digunakan untuk membiayai kegiatan pemerintah. Pemerintah daerah diberikan wewenang untuk mengatur dan mengurus rumah tangga daerahnya, dengan kata lain dengan cara menggali segala kemungkinan sumber keuangan sendiri. Pemanfaatan sumber daya nasional yang berkeadilan serta perimbangan keuangan antara pusat dan daerah. Dengan demikian pemerintah daerah diharapkan lebih mengerti dan memenuhi aspirasi masyarakat di daerahnya 
agar dapat mendorong timbulnya prakarsa dan pelaksanaan pembangunan yang merupakan prasyarat keberhasilan pelaksanaan pemerintah. Kemampuan pemerintah dalam mengelola keuangannya dituangkan dalam Anggaran Pendapatan dan Belanja Daerah (APBD) yang menggambarkan kemampuan pemerintah daerah dalam membiayai kegiatan tugas pembangunan. Anggaran daerah atau lebih dikenal dengan sebutan APBD merupakan suatu kebijakan yang utama bagi Pemerintah Daerah. Anggaran daerah menduduki posisi sentral dalam upaya pengembangan kapabilitas dan efektivitas pemerintah daerah. Anggaran daerah seharusnya dipergunakan sebagai alat untuk menentukan besarnya pendapatan, pengeluaran dan pembiayaan, alat bantu pengambilan keputusan dan perencanaan pembangunan, alat otoritas pengeluaran dimasa yang akan datang, ukuran standar untuk evaluasi kinerja, serta alat koordinasi bagi semua aktivitas diberbagai unit kerja. Penilaian kinerja dilakukan agar dapat mengetahui sejauh mana pemerintah menjalankan tugasnya dalam roda pemerintahan dan melaksanakan pembangunan serta pelayanan kepada masyarakat dengan menyampaikan laporan pertanggungjawaban keuangan.Tuntutan yang tinggi terhadap kinerja dan akuntabilitas kinerjapemerintah daerah ini beruung pada kebutuhan pengukuran kinerja pemerintah daerah. Pengukuran kinerja pemerintah daerah mempunyai banyak tujuan, tujuan tersebut paling tidak untuk meningkatkan kinerja dan meningkatkan akuntabilitas pemerintah daerah.Maka daripada itu pemerintah daerah dituntut untuk mampu membangun ukuran kinerja yang baik (Mardiasmo, 2002:299). Dalam UU No. 32 tahun 2004 pasal 6 ayat (2) menjelaskan evaluasi terhadap kemampuan pemerintah daerah adalah dengan penilaian menggunakan sistem pengukuran kinerja serta indikator-indikatornya yang meliputi masukan, keluaran, hasil, manfaat dan dampak.

Pemerintah adalah suatu organisasi yang diberi kekuasaan untuk mengatur kepentingan Bangsa dan Negara. Lembaga pemerintah dibentuk umumnya untuk menjalankan aktivitas layanan terhadap masyarakat luas dan sebagai organisasi nirlaba yang mempunyai tujuan bukan untuk mencari keuntungan tetapi untuk menyediakan layanan dan kemampuan meningkatkan layanan tersebut di masa yang akan datang. Tujuan yang akan dicapai biasanya ditentukan dalam bentuk kualitatif, misalnya meningkatkan kenyamanan dan keamanan, mutu pendidikan, kesehatan maupun keimanan. Pada era globalisasi saat ini yang merupakan sesuatu yang tidak dapat dihindari oleh seluruh masyarakat dunia. Bangsa Indonesia merupakan bagian dari masyarakat dunia yang memiliki kewajiban untuk secara terus menerus berpartisipasi dalam mewujudkan pemerintahan yang baik (good governance) untuk menunjang dalam persaingan di era globalisasi. Menanggapi paradigma baru tersebut maka pemerintah memberikan otonomi kepada daerah seluas-luasnya yang bertujuan untuk memungkinkan daerah mengurus dan mengatur rumah tangganya sendiri agar berdaya guna dan berhasil guna dalam penyelenggaraan pemerintahan dan pembangunan serta dalam rangka pelayanan kepada masyarakat. Upaya konkret dalam mewujudkan akuntabilitas dan transparasi di lingkungan pemerintah mengharuskan setiap pengelola keuangan negara untuk menyampaikan laporan pertanggungjawaban pengelolaan keuangan dengan cakupan yang lebih luas dan tepat waktu. Undang-undang nomor 17 tahun 2003 tentang Keuangan Negara menegaskan bahwa laporan pertanggungjawaban keuangan dimaksud dinyatakan dalam bentuk laporan keuangan yang setidaktidaknya meliputi laporan realisasi anggaran, neraca, laporan arus kas, dan catatan atas laporan keuangan, dan disusun berdasarkan SAP. Berlakunya otonomi daerah memberikan kewenangan kepada daerah untuk mengelola dan memanfaatkan 
sumber-sumber keuangan secara langsung. Daerah mempunyai tanggung jawab untuk melaksanakan pembangunannya disegala bidang. Maka dari itu perlu dirumuskan suatu perencanaan daerah dan Anggaran Pendapatan dan Belanja Daerah. Faktor penunjang dalam kegiatan pembangunan di daerah adalah potensi keuangan daerah khususnya Pendapatan Asli Daerah.

Anggaran Pendapatan dan Belanja Daerah merupakan rencana keuangan tahunan pemerintah daerah yang disetujui oleh Dewan Perwakilan Rakyat Daerah. Menurut UU No. 33 Tahun 2004, APBD adalah suatu rencana keuangan tahunan yang ditetapkan berdasarkan peraturan daerah. Menurut Saragih (2003:127), APBD merupakan suatu gambaran atau tolak ukur penting keberhasilan suatu daerah dalam meningkatkana potensi perekonomian daerah. Artinya, jika perekonomian daerah mengalami pertumbuhan maka akan berdampak positif terhadap Pendapatan Asli Daerah (PAD). Kepmendagri No. 29 Tahun 2002 mengatakan bahwa penyusunan Anggaran Pendapatan dan Belanja Daerah (APBD) hendaknya mengacu pada norma dan prinsip anggaran sebagai berikut:

1. Transparansi dan akuntabilitas anggaran

2. Disiplin Anggaran

3. Keadilan Anggaran

4. Efektifitas dan Efeisiensi Anggaran

5. Format Anggaran.

Unsur-unsur APBD menurut Halim (2004:15-16), yaitu sebagai berikut:

1. Rencana kegiatan suatu daerah beserta uraiannya secara rincil

2. Adanya sumber penerimaan yang merupakan target minimal untuk menutupi biaya-biaya sehubungan dengan aktivitas tersebut, dan adanya biaya-biaya yang merupakan batas maksimal pengeluaran-pengeluaran yang akan dilaksanakan

3. Jenis kegiatan dan proyek yang dituangkan dalam bentuk angka

4. Periode anggaran yang biasanya satu tahun

Sedangkan Pendapatan Daerah adalah pendapatan yang dianggarkan dalam APBD meliputi semua penerimaan uang melalui rekening kas umum daerah yang menambah ekuitas dana, serta merupakan hak daerah dalam satu tahun anggaran yang tidak perlu dibayar kembali oleh daerah. Menurut Permendagri No. 13 Tahun 2006 Pasal 22 Ayat 1, pendapatan daerah dikelompokkan atas Pendapatan Asli Daerah (PAD), dana perimbangan, dan lain-lain pendapatan daerah yang sah. PAD sendiri terdiri dari:

1. Pajak daerah

2. Retribusi daerah

3. Hasil pengelolaan kekayaan daerah yang dipisahkan

4. Lain-lain pendapatan daerah yang sah.

UU No. 34 Tahun 2000 tentang perubahan atas UU No. 18 Tahun 1997 tentang pajak daerah dan retribusi daerah, Saragih (2003:61) menjelaskan bahwa yang dimaksud dengan pajak daerah adalah iuran wajub yang dilakukan oleh orang pribadi dan badan kepada daerah tanpa imbalan langsung yang seimbang yang dapat dipaksakan berdasarkan perundang-undangan yang berlaku yang digunakan untuk membiayai penyelenggaraan pembangunan pemerintah daerah. Sedangkan menurut Halim (2004:67) mengatakan bahwa pajak daerah merupakan pendapatan daerah daerah yang beasal dari pajak. Jenis-jenis pajak daerah untuk kabupaten/kota menurut Kadjatmiko (2002:77) antara lain adalah: pajak hotel, pajak restoran, pajak hiburan, pajak reklame, pajak penerangan jalan, pajak pengambilan bahan galian golongan C dan pajak parkir. Retribusi menurut Saragih (2003:65) adalah pungutan daerah sebagai pembayaran atas jasa atau pemberian ijin tertentu yang khusus 
diberikan oleh daerah kepada pribadi/badan utnuk kepentingan pribadi. Menurut Halim (2004:68), hasil perusahaan milik daerah dan hasil pengelolaan kekayaan milik daerah yang dipisahkan adalah jenis pendapatan yang meliputi objek pendapatan yang terdiri dari :

1. Bagian laba perudahaan milik daerah

2. Bagian laba lembaga keuangan bank

3. Bagian laba keuangan non-bank

4. Bagian laba aras penyertaan modal/investasi.

Lain-lain pendapatan asli daerah yang sah menurut Halim (2004:69) adalah jenis pendapatan yang meliputi objek pendapatan :

1. Hasil penjualan aset daerah yang tidak dipisahkan

2. Penerimaan jasa giro

3. Penerimaan bunga deposito

4. Denda keterlambatan pelaksanaan pekerjaan

5. Penerimaan ganti rugi atas kerugian/kehilangan kekayaan daerah.

Belanja daerah adalah semua yang merupakan kewajiban daerah yang diakui sebagai pengurangan nilai kekayaan daerah dalam periode tahun anggaran yang bersangkutan. Berdasarkan Kepmendagri No. 29 tahun 2002, belanja terdiri dari :

1. Belanja aparatur daerah

2. Belanja pelayanan public

3. Belanja bagi hasil dan bantuan keuangan

4. Belanja tidak tersangka.

Sedangkan berdasarkan Permendagri No. 13 tahun 2006 yang direvisi dengan Permendagri No. 59 Tahun 2007, terdapat 2 jenis belanja menurut kelompok belanja, yaitu belanja langsung dan belanja tidak langsung.

Upaya untuk melakukan peningkatan pendapatan asli daerah dapat dilakukan dengan mengintensifkan pengkajian dan penggalian potensi keuangan daerah, yang dapat dilakukan dengan cara intensifikasi dan ekstensifikasi yang salah satunya dengan meningkatkan efektivitas pemungutan yaitu dengan mengoptimalkan potensi yang ada dengan terus menggali sumber-sumber pendapatan baru yang potensial yang memungkinkan untuk dapat dipunggut pajaknya. Penyediaan dana bagi pembangunan daerah harus diusahakan sedapat mungkin dapat terealisasi dalam jumlah besar. Karena pembangunan daerah memerlukan biaya yang terus meningkat. Pendapatan daerah di Kabupaten Batang Hari dapat digolongkan atas pendapatan pajak dan non pajak. Salah satu pendapatan pajak adalah dari pajak daerah. Dalam rangka mendukung dan menyelenggarakan otonomi daerah yang luas, nyata da bertanggung jawab, maka dibutuhkan sumber dana pembangunan yang besar. Dana-dana untuk menyelenggarakan pembangunan tersebut salah satunya berasal dari Pendapatan Asli Daerah. Realisasi dan Peningkatan Pendapatan Asli Daerah diharapkan akan dapat terus meningkatkan kemandirian daerah dalam membiayai pembangunan daerah. Sejalan dengan hal tersebut pajak daerah jenis Pajak Reklame merupakan salah satu sumber pendapatan asli daerah dalam menunjang otonomi daerah. Peningkatan Penerimaan pajak daerah akan bisa memberikan kontribusi yang besar pada peningkatan Pendapatan Asli Daerah. Pemanfaatan dan pengelolaan sumber-sumber pajak daerah akan mempengaruhi besarnya Pendapatan Asli Daerah. Dari uraian diatas maka penulis tertarik untuk melakukan penelitian dengan judul : Analisis Kinerja Pendapatan Asli Daerah Kabupaten Batanghari 2012-2016.

Dari Uraian latar belakang diatas dapat dirumuskan masalah penelitian yaitu, Bagaimana Kinerja Pendapatan Asli Daerah Kabupaten Batanghari periode 2012- 
2016, dengan ruang lingkup pembahasan, Perkembangan PAD, Efektifitas PAD dan Kemandirian Keuangan daerah Kabupaten Batanghari selama 2012-2016, sedangkan Tujuan dari penelitian ini adalah : 1) Untuk mengetahui Perkembangan Pendapatan Asli Daerah (PAD) Kabupaten Batanghari 2012-2016. 2) Untuk mengetahui dan menganalisis rasio efektifitas Pendapatan Asli Daerah Kabupaten Batanghari 2012-2016. 3) Untuk Mengetahui dan menganalisis rasio kemandirian keuangan kabupaten Batanghari

\section{METODE PENELITIAN}

Jenis data yang digunakan dalam penelitian ini adalah sekumpulan informasi atau fakta yang dicatat melalui pengamatan langsung dan survei ( Indrianto dan Supomo ; 2009:249 ), sehingga jenis data tersebut menjadi dua Jenis yaitu :

1. Data kualitatif adalah data-data yang tidak berwujud angka, berupa gambaran umum perusahaan dan struktur organisasi.

2. Data kuantitatif adalah data yang berwujud angka, berupa data-data keuangan perusahaan atau organisasi.

Dalam penelitian ini penulis menggunakan kedua jenis data tersebut yaitu data laporan realisasi APBD Kabupaten Batanghari tahun 2008-2016, yang kemudian dijadikan sebagai data Kualitatif.

Sedangkan Sumber data yang digunakan adalah sumber data sekunder dan sumber data primer yang diperoleh dari :

1. Kantor Badan Keuangan Daerah Kabupaten Batang Hari

2. Badan Pusat Statistik Kabupaten Batang Hari

3. Kantor Bappeda Kabupaten Batang Hari

Metode analisis yang digunakan adalah deskriptif dimana sifatnya menguraikan dan menggambarkan suatu data atau keadaan serta melukiskan atau menjelaskan sedemikian rupa sehingga dapat ditarik kesimpulan untuk menjawab permasalahan yang ada. Terdapat 2 perhitungan dalam metode analisis yaitu analisis kinerja pendapatan dan analisis kinerja belanja dimana didalamnya juga terdapat rasio-rasio perhitungan untuk membantu dalam penelitian ini yaitu:

1. Analisis Perkembangan PAD

Analisis Perkembangan Pendapatan Asli Daerah menggambarkan tingkat perkembangan PAD tahun analisis dengan tahun sebelumnya yang dapat dihitung dengan menggunakan rumus :

$$
\begin{aligned}
& P A D_{t}-P_{A D} \\
& \text { Perkembangan PAD = --------------------- X 100\% } \\
& \mathrm{PAD}_{\mathrm{t}-1}
\end{aligned}
$$

Dimana :

PAD $_{\mathrm{t}} \quad=$ PAD Tahun Analisis

$\mathrm{PAD}_{\mathrm{t}-1}=\mathrm{PAD}$ Tahun Sebelumnya

2. Analisis Rasio Efektivitas PAD

Rasio efektifitas menggambarkan kemampuan pemerintah daerah dalam merealisasikan pendapatan asli daerah yang direncanakan dibandingkan dengan target yang di tetapkan berdasarkan potensi riil daerah yang dapat dihitung dengan rumus sebagai berikut :

Realisasi PAD

$$
\begin{gathered}
\text { Rasio Efektifitas PAD = ------------------------ X 100\% } \\
\text { Target Penerimaan PAD } \\
\text { Efektivitas Menurut Siagiaan yang dikutip oleh Mamuaja (2016) } \\
\text { mendefinisikan efektivitas adalah pemanfaatan sumber daya, sarana, dan }
\end{gathered}
$$


prasarana dalam jumlah tertentu yang secara sadar ditetapkan sebelumnya untuk menghasilkan sejumlah barang atas jasa kegiatan yang dijalankannya. Dikatakan efektif apabila proses kegiatan mencapai tujuan dan sasaran akhir kebijakan. Semakin besar ouput yang dihasilkan terhadap pencapaian tujuan dan sasaran yang ditentukan, maka semakin efektif proses kerja suatu unit organisasi. Pajak daerah dapat dikategorikan tingkat efektivitasnya sebagai berikut:

a. Tingkat pencapaian di atas $100 \%$ berarti sangat efektif.

b. Tingkat pencapaian antara $90 \%-100 \%$ berarti efektif.

c. Tingkat pencapaian antara $80 \%-90 \%$ berarti cukup efektif.

d. Tingkat pencapaian antara $60 \%-80 \%$ berarti kurang efektif.

3. Analisis Rasio Kemandirian

Kemandirian keuangan daerah menunjukan kemampuan pemerintah daerah dalam membiayai sendiri kegiatan pemerintah, pembangunan dan pelayanan kepada masyarakat yang telah membayar pajak dan retribusi sebagai sumber pendapatan yang diperlukan daerah. Jadi rasio kemandirian keuangan daerah merupakan perbandingan antara PAD dengan pendapatan daerah yang berasal dari sumber lain, misalnya bantuan pemerintah pusat atau dari pinjaman. Rasio kemandirian tersebut dapat diformulasikan sebagai berikut :

\section{PAD}

Rasio Kemandirian $=$ X $100 \%$

Transfer Pusat + Propinsi dan Pinjaman

Dengan kriteria pengukuran mengunnakan skala interval kemandirian yang disusun oleh Litbang Depdagri (1991) :

\begin{tabular}{cc}
\hline Presentasi & Kemandirian \\
\hline $0,00 \%-10,00 \%$ & Sangat Kurang \\
$10,01 \%-20,00 \%$ & Kurang \\
$20,01-30,00 \%$ & Sedang \\
$30,01 \%-40,00 \%$ & Cukup \\
$40,01 \%-50,00 \%$ & Baik \\
$>50,00 \%$ & Sangat Baik \\
\hline
\end{tabular}

\section{HASIL DAN PEMBAHASAN}

\section{Perkembangan Pendapatan Asli Daerah}

Perkembangan Pendapatan Asli Daerah Kabupaten Batanghari 2012-2016 dapat dilihat dari tabel dibawah ini :

\begin{tabular}{cccc}
\hline TAHUN & PAD & PERKEMBANGAN \\
\hline 2012 & $\mathrm{Rp}$ & 37.229 .501 .178 & \\
2013 & $\mathrm{Rp}$ & 50.623 .238 .098 & $35,98 \%$ \\
2014 & $\mathrm{Rp}$ & 70.804 .984 .188 & $39,87 \%$ \\
2015 & $\mathrm{Rp}$ & 68.925 .399 .899 & $-2,65 \%$ \\
2016 & $\mathrm{Rp}$ & 73.353 .584 .659 & $6,42 \%$ \\
\hline
\end{tabular}

Dari tabel diatas terlihat bahwa terjadi perkembangan PAD yang fluaktiatif dari tahun 2012 sampai dengan 2016, pada tahun 2013 terjadi peningkatan PAD sebesar 35,98\% dari realisasi PAD tahun sebelumnya, sedangkankan pada tahun 2014 terjadi peningkatan PAD sebesar 39,87\%, tetapi pada tahun 2015 terjadi penurunan realisasi PAD sebesar $2,65 \%$, penurunan ini salah satunya diakibatkan oleh Realisasi penerimaan Pajak Bumi dan Bangunan (PBB) sektor 
perdesaan dan perkotaan di Kabupaten Batanghari pada tahun 2015 menurun sebagai dampak dari turunnya harga kelapa sawit dan karet. Penurunan wajib PBB ini berdasarkan data realisasi penerimaan PBB per kecamatan terhitung sejak Januari hingga September 2015. Untuk tahun 2016 kembali terjadi peningkatan Pendapatan Asli Daerah Kabupaten Batanghari sebesar 6,42\% dibandingkan dengan tahun sebelumnya.

\section{Analisis Rasio Efektifitas Pendapatan Asli Daerah (PAD)}

Efektivitas merupakan ukuran keberhasilan suatu organisasi, baik pemerintah maupun swasta dalam mewujudkan tujuannya. efektivitas PAD dinilai dari perbandingan realisasi PAD dan target PAD, Efektifitas PAD Kabupaten Batanghari 2012-2016 dapat dilihat dari tabel berikut:

\begin{tabular}{llllcc}
\hline Tahun & & Target PAD & \multicolumn{2}{c}{ Realisasi PAD } & Efektifitas \\
\hline 2012 & $\mathrm{Rp}$ & 44.276 .720 .650 & $\mathrm{Rp}$ & 37.229 .501 .178 & $84 \%$ \\
2013 & $\mathrm{Rp}$ & 46.118 .485 .212 & $\mathrm{Rp}$ & 50.623 .238 .098 & $110 \%$ \\
2014 & $\mathrm{Rp}$ & 68.710 .435 .721 & $\mathrm{Rp}$ & 70.804 .984 .188 & $103 \%$ \\
2015 & $\mathrm{Rp}$ & 80.687 .303 .704 & $\mathrm{Rp}$ & 68.925 .399 .899 & $85 \%$ \\
2016 & $\mathrm{Rp}$ & 89.565 .435 .754 & $\mathrm{Rp}$ & 73.353 .584 .659 & $82 \%$ \\
\hline
\end{tabular}

Untuk hasil efektifitas PAD Kabupaten Batanghari dapat dilihat hasil perhitungan yang menunjukkan bahwa pada tahun 2012 tingkat efektifitasnya 84\% yang dikategorikan cukup efektif sedangkan pada tahun 2013 dan 2014 masing-masing $110 \%$ dan $103 \%$ dikategorikan sangat efektif, dan untuk tahun 2015 dan 2016 Pendapatan Asli daerah Kabupaten Batanghari dikaterikan cukup efektif dengan nilai efektifitasnya masing-masing $85 \%$ dan $82 \%$.

\section{Rasio Kemandirian}

Dalam menilai kemandirian suatu daerah dilihat dari kemampuan PAD terhadap transfer pusat, propinsi dan pinjaman, terlihat pada tabel bawah ini :

\begin{tabular}{ccccrc}
\hline Tahun & Realisasi PAD & \multicolumn{2}{c}{$\begin{array}{c}\text { Transfer Pusat+Propinsi dan } \\
\text { Pinjaman }\end{array}$} & $\begin{array}{c}\text { Rasio } \\
\text { Kemandirian }\end{array}$ \\
\hline 2012 & $\mathrm{Rp}$ & 37.229 .501 .178 & $\mathrm{Rp}$ & 766.562 .148 .352 & $4,86 \%$ \\
2013 & $\mathrm{Rp}$ & 50.623 .238 .098 & $\mathrm{Rp}$ & 898.074 .198 .560 & $5,64 \%$ \\
2014 & $\mathrm{Rp}$ & 70.804 .984 .188 & $\mathrm{Rp}$ & 878.961 .220 .495 & $8,06 \%$ \\
2015 & $\mathrm{Rp}$ & 68.925 .399 .899 & $\mathrm{Rp}$ & 846.430 .746 .207 & $8,14 \%$ \\
2016 & $\mathrm{Rp}$ & 73.353 .584 .659 & $\mathrm{Rp}$ & 1.001 .929 .237 .037 & $7,32 \%$ \\
\hline
\end{tabular}

Dari tabel diatas memperlihatkan persentase kemandirian PAD Kabupaten Batanghari setiap tahunnya, yang merupakan hasil perbandingan antara PAD dengan bantuan pemerintah pusat/provinsi dan pinjaman dari tahun 2012-2016. Tabel tersebut menunjukkan bahwa rasio kemandirian pemungutan PAD di Kabupaten Batanghari tahun anggaran 2012-2016 sesuai dengan kriteria rentang skala kemandirian menunjukkan angka dibawah $10,00 \%$ yang artinya kemandirian Keuangan Kabupaten Batanghari sangat kurang, walaupun setiap tahunnya cenderung fluktuatif. Dilihat dari hasil perhitungan rasio kemandirian pada tahun 2012, hanya diangka 4,86\% kemudian meningkat pada tahun 2015 sebesar 5,64\% pada tahun 2014 dan 2015 kemandirian Keuangan Kabupaten Batanghari naik pada angka masing-masing $8,04 \%$ dan $8,14 \%$ tetapi pada tahun 2016 kembali terjadu penurunan sebesar 7,32 \%, hal ini menunjukkan bahwa pemerintah daerah belum mampu atau sementara mengembangkan Pendapatan 
Asli Daerah sebagai salah sumber utama untuk dapat membiayai sendiri kegiatan pemerintah, pembangunan dan pelayanan kepada masyarakat yang telah membayar pajak dan retribusi sebagai sumber pendapatan yang diperlukan daerah.

\section{SIMPULAN}

Perkembangan PAD kabupaten Batanghari dari tahun 2012 sampai dengan 2016 adalah fluktuatif, pada tahun 2013 terjadi peningkatan PAD sebesar 35,98\% dari realisasi PAD tahun sebelumnya, sedangkankan pada tahun 2014 terjadi peningkatan PAD sebesar 39,87\%, tetapi pada tahun 2015 terjadi penurunan realisasi PAD sebesar 2,65\%, penurunan ini salah satunya diakibatkan oleh Realisasi penerimaan Pajak Bumi dan Bangunan (PBB) sektor perdesaan dan perkotaan di Kabupaten Batanghari pada tahun 2015 menurun sebagai dampak dari turunnya harga kelapa sawit dan karet. Penurunan wajib PBB ini berdasarkan data realisasi penerimaan PBB per kecamatan terhitung sejak Januari hingga September 2015. Untuk tahun 2016 kembali terjadi peningkatan Pendapatan Asli Daerah Kabupaten Batanghari sebesar 6,42\% dibandingkan dengan tahun sebelumnya.

Untuk hasil efektifitas PAD Kabupaten Batanghari menunjukkan bahwa pada tahun 2012 tingkat efektifitasnya $84 \%$ yang dikategorikan cukup efektif sedangkan pada tahun 2013 dan 2014 masing-masing 110\% dan 103\% dikategorikan sangat efektif, dan untuk tahun 2015 dan 2016 Pendapatan Asli daerah Kabupaten Batanghari dikaterikan cukup efektif dengan nilai efektifitasnya masing-masing $85 \%$ dan $82 \%$. Sedangkan kinerja PAD dilihat dari kemandirian keuangan, dari hasil perhitungan sesuai dengan skala interval, kemandirian keuangan batanghari berada dibawah 10\%, artinya kemandirian Keuangan Kabupaten Batanghari sangat kurang.

\section{DAFTAR PUSTAKA}

Yaneka Julastiana Dan I Wayan Suartana. 2007. Analisis Efisiensi Dan fektivitas Penerimaan Pendapatan Asli Daerah Kabupaten Klungkung. Fakultas Ekonomi Universitas Udayana (Unud), Bali, Indonesia

Magdalena, Rombang. 2013. Analisis Kinerja Pendapatan Asli Daerah (PAD) Di Provinsi Sulawesi Utara Tahun 2008-2012. Skripsi Universitas Sam Ratulangi Manado.

Marchelino Daling. 2013. Analisis Kinerja Realisasi Anggaran Pendapatan Dan Belanja Pemerintah Kabupaten Minahasa Tenggara. Jurnal EMBA Vol.1 No.3 September 2013, Hal. 82-89

Kevin R.M. Mandey Dan Tri Oldy Rotinsulu. 2015. Analisis Kinerja Pendapatan Asli Daerah Dikaitkan Dengan Belanja Daerah Pada Pemerintah Kota Bitung. Jurnal EMBA 827 Vol.3 No.3 Sept. 2015, Hal.827-838

Nona Nelly Bawuna, Lintje Kalangi Dan Treesje Runtu.2016. Analisis Efektivitas Kinerja Penerimaan Pajak Daerah Dan Retribusi Daerah Terhadap Pendapatan Asli Daerah Di Kabupaten Siau Tagulandang Biaro. Jurnal Berkala Ilmiah Efisiensi Volume 16 No. 04 Tahun 2016

Mamuaja, Brejita. 2016. Analisis Efektivitas Penerapan Sistem Pengendalian Intern Terhadap Kinerja Instansi Pemerintah Di Dinas Pendapatan Kota Manado. ISSN 2303-1174.Jurnal EMBA. Vol.4 No.1. Hal. 165-171. 